\title{
SOME OBSERVATIONS OF CAPTIVE GIANT WATER BUGS
}

\author{
by J. E. Guthrie and S. L. Iverson, \\ Whiteshell Nuclear Research Establishment, Pinawa, Manitoba
}

We have used the giant water bug, Lethocerus americanus (Leidy), Hemiptera: Belostomatidae, to study the use of radiocesium $\left({ }^{137} \mathrm{Cs}\right)$ for the determination of food consumption by an aquatic insect which has piercingsucking mouthparts. During this work, we made some observations of the habits of these insects.

$L$. americanus is one of several species of the family Belostomatidae found in the prairie provinces (Brooks and Kelton, 1967). In the vicinity of Pinawa, Manitoba, ponds and quiet pools in streams are typical habitats We have also seen them near the banks of the Winnipeg River. The giant water bug has been called the "fish killer" and, because it is attracted to electric lights, the "electric light bug" (Cummings, 1933). It is a dark brown insect, about $5 \frac{1}{2} \mathrm{~cm}$ (2 in.) long and $1 \frac{1}{2} \mathrm{~cm}\left(\frac{3}{4}\right.$ in.) across the widest part of the body. The photographs, taken in the laboratory, show some of the features of the insect as well as give an impression of some of its habits and habitat. The insect's antennae do not appear in any of the photographs, because they are concealed in pockets beneath the eyes. This is a convenient arrangement for an insect which seeks its food in a tangle of underwater vegetation.

The giant water bug is a predaceous insect which captures and sucks out the juices of other insects, tadpoles, and small fish. At Pinawa, we have watched them capture and feed upon predaceous diving beetles ( $D y$ tiscus spp.) as big as themselves, and on small frogs (Rama sp.). The giant water bug's bite is said to be quite painful (Batchley, 1926; Brooks and Kelton, 1967) ; but neither of us was eager to test this observation.

\section{Laboratory Observations}

Because of their predaceous characteristics, giant water bug nymphs and adults were kept in individual quart-size plastic food-freezer boxes with small holes in their lids. A small block of wood in each box provided a resting place for the insect. When disturbed or frightened, resting giant water bugs often ejected from the anal region, a dark green liquid with a peculiar fishy odor. This liquid may be comparable to the squid's ink cloud, or it may be an expulsion of the gut contents. Although most aquatic insects are probably silent, nymph and adult water bugs often made distinct squeaking and wheezing noises.

Our giant water bug nymphs (instars I to V) and adults were fed live tadpoles, except in some experiments in which they were offered small frogs. Tadpoles were attacked and seized by the grasping (raptorial) forelegs, then pierced with the beak. All that remained of the tadpole after it had been fed upon was its shrivelled

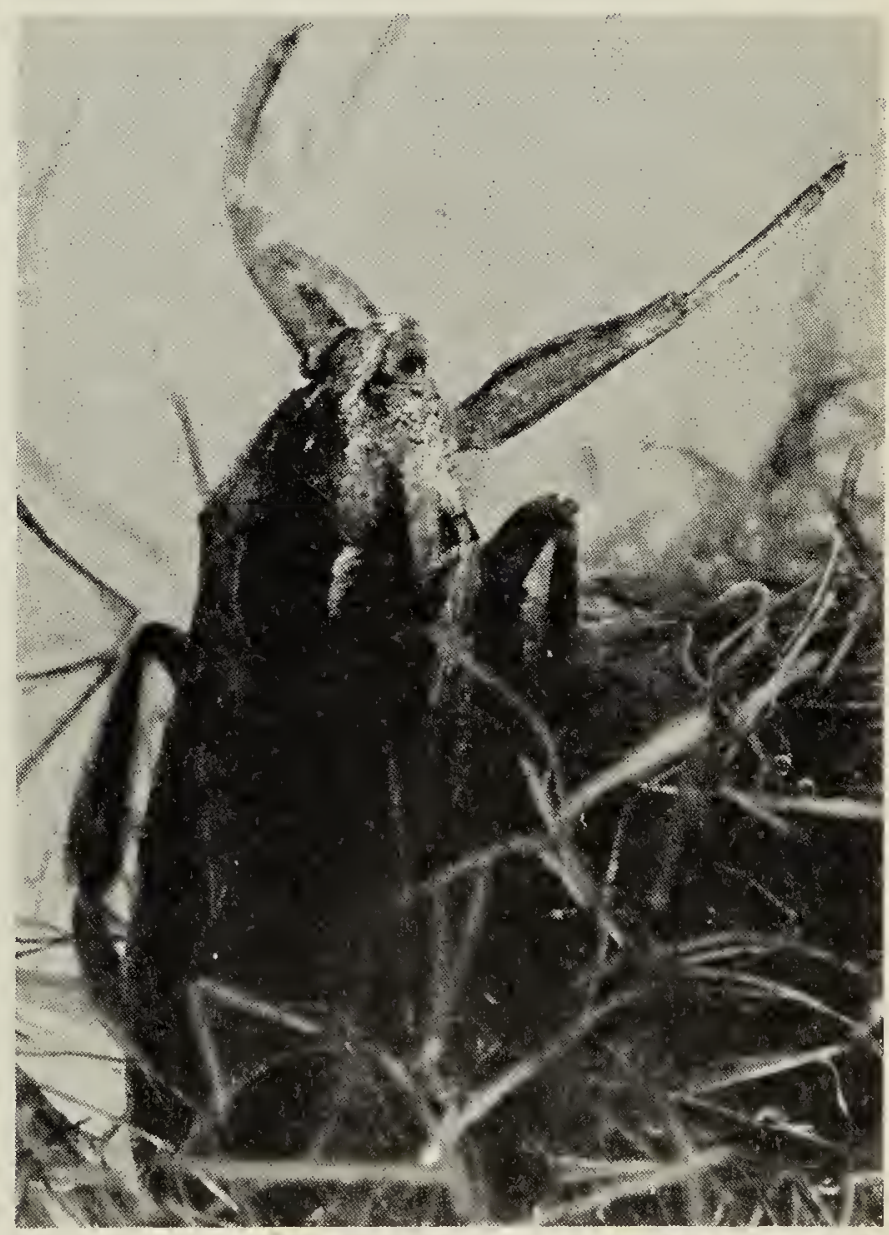

Fig. 1. Giant Water Bug in partially concealed position. 
skin and some dark mud-like material in the digestive tract. Those tadpoles pierced at the base of the tail were quickly immobilized, even though some were larger than the nymph. Rankin (1935) suggested that the insect's saliva contains a poison which causes paralysis. The saliva may also contain enzymes which digest or liquefy the victim's tissues. Rees and Offord (1969) have isolated enzymes (proteases) which break down proteins from the salivary glands of a tropical giant water bug, Lethocerus cordofanus Mayr.

Our experiments (Guthrie and Brust, 1969) required that the giant water bugs be fed tadpoles or frogs one at a time to ensure that all food was eaten. Before being fed, the insects rested partially concealed in a waiting posture, with forelegs outstretched, as shown in Figure 1. If the victim swam past within lunging distance, it was instantly seized, the beak inserted, and feeding began. If the victim kept its distance, which it often did, the water bug gave chase (Cover illus.). As might be expected, hungry bugs chased prey more vigorously than ones that had been recently fed. Eventually, the victim was seized with the forelegs. Larger animals such as frogs or fishes resisted capture. If the quarry was struggling violently, the bug did not attempt to insert its beak-a water bug with a broken beak is doomed to starvation since it cannot grow another. The viatim was held, sometimes with all six legs, until it drowned or became exhausted. Then the beak was inserted and feeding began (Figure 2).

Adult giant water bugs which had been fed their tadpole ration with forceps for seven to ten days became "lazy" and made no effort to pursue prey which slipped away. It seemed that the insects expected dinner to be served between their forelegs. If deprived of table-service for three or

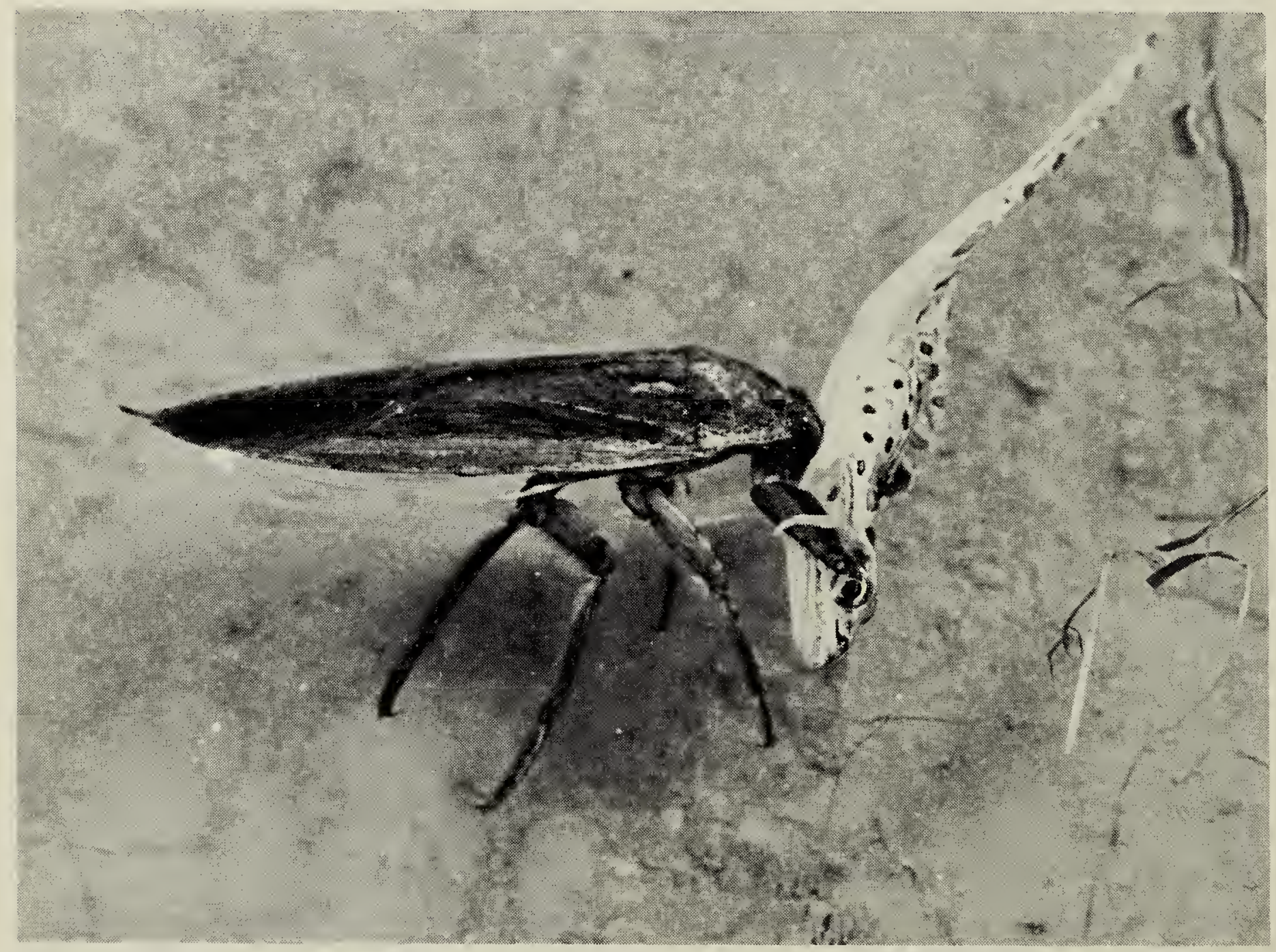

Fig. 2. The victim has been subdued. The Giant Water Bug has inserted its beak through the thin skin covering the frog's abdomen. 


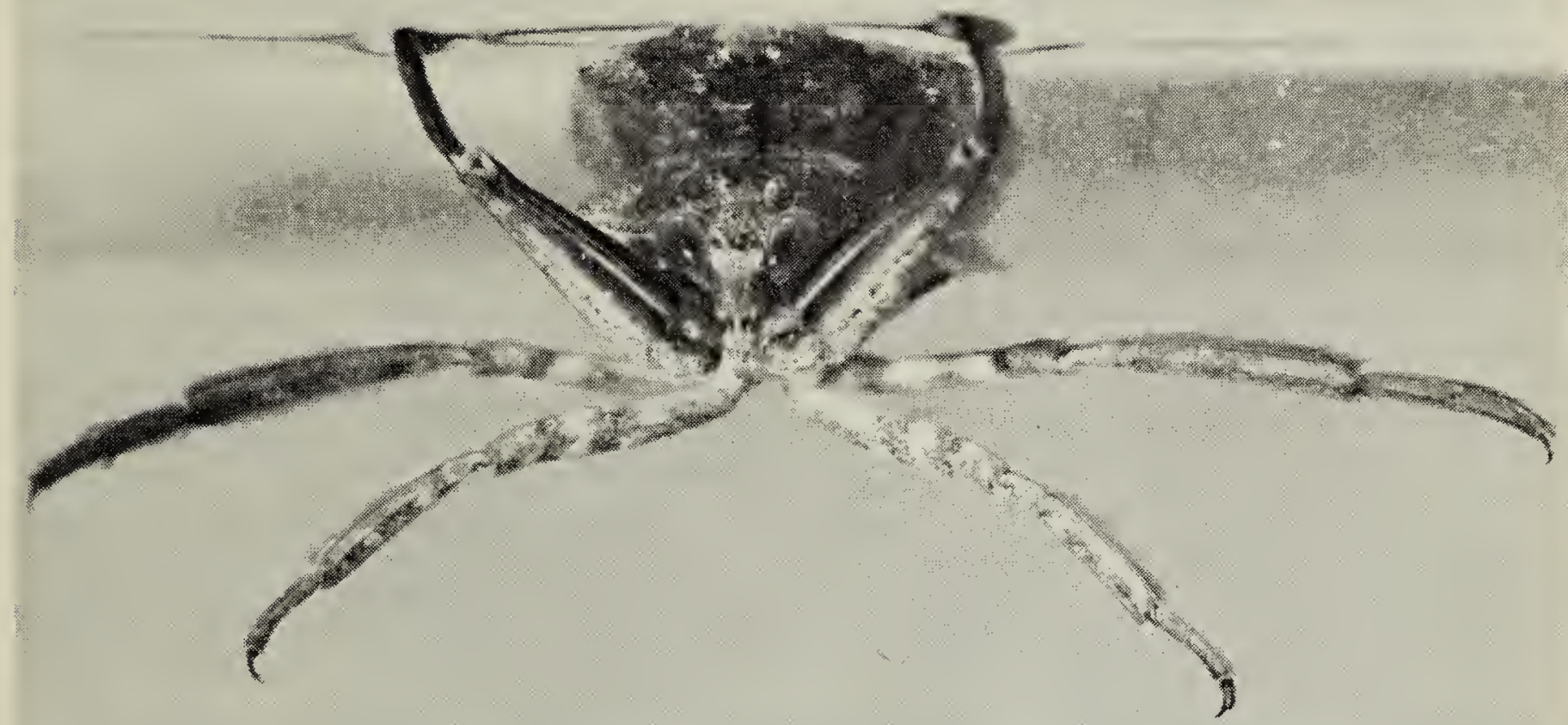

Fig. 3. Head-on view of an adult giant water bug, Lethocerus americanus (Leidy). The grasping forelegs are seen just breaking the surface of the water. The large, stout beak or proboscis is between the forelegs. The prominent groove in the femur of the forelegs is one of the distinguishing features of this species.

four days, however, they began to chase their food again.

How these bugs survive over winter is not known. They may burrow into the mud in the margins of ponds and streams, but we have no evidence of this. We marked a number of adults living in a pond in late September, but none were found the following spring. They may have migrated to other ponds before freeze-up or immediately following the spring thaw. We did note, however, that water bugs in the laboratory became "restless" as summer waned. During the summer the adults seldom attempted to escape from their plastic boxes when the covers were removed, but as autumn advanced attempts to escape became more frequent. How the adult giant water bug survives the winter and the duration of overwintering are two questions to which those who are interested in observing aquatic habitats could contribute significant in- formation. The size, availability, and interesting habits of this insect make it good material for observation by naturalists or biology students.

\section{LITERATURE CITED}

Batchley, W. C. 1926. Heteroptera or true bugs of eastern North America with special reference to the faunae of Indiana and Florida. Nature Publishing Co., Indianapolis.

Brooks, A. R., and L. A. Kelton. 1967. Aquatic and semiaquatic Heteroptera of Alberta, Saskatchewan, and Manitoba (Hemiptera). Mem. Ent. Soc. Can. No. 51.

Cummings, C. 1933. The giant water bugs (Belostomatidae: Hemiptera). Kans. Univ. Sci. Bull. 21 :197-219.

Guthrie, J. E., and R. A. Brust. 1969. Elimination rate of radiocesium by an aquatic Hemipteran Lethocerus americanus (Leidy). Can. Ent. $101: 856-861$.

Hoffman, W. E. 1924. Biological notes on Lethocerus americans (Leidy). Psyche Comb. $31: 175-183$.

Rankin, K. P. 1935. Life history of Lethocerus americanus (Leidy) (Hemiptera: Belostomatidae). Kans. Univ. Sci. Bull. $22: 479-491$.

Rees, A. R., and R. E. Offord. 1969. Studies on protease and other enzymes from the venom of Lethocerus cordofanus. Nature $221: 675-677$. 